\title{
ПІДГОТОВКА ФАХІВЦІВ ГАЛУЗІ ГЕОДЕЗІЇ ТА ЗЕМЛЕУСТРОЮ В УМОВАХ ГЛОБАЛІЗАЦІї ТА ЄВРОІНТЕГРАЦІї
}

\author{
Русіна Н. Г. \\ кандидат педагогічних наук, \\ викладач технічного відділення \\ Рівненський коледж \\ Національного університету біоресурсів і природокористування Украӥни \\ вул. Коперніка, 44, Рівне, Україна \\ orcid.org/0000-0001-5826-8788 \\ RusinaN@i.ua
}

\begin{abstract}
Ключові слова:
землеустрій, фахівецьь галузі геодезї та землеустрою, модернізація галузі, структурна модель підготовки, діагностичні методики перевірки сформованості компонентів готовності, інформаційні технологіï, традиціиині й інтерактивні методи.
\end{abstract}

У статті проаналізовано сучасні тенденції підготовки фахівців геодезії та землеустрою з урахуванням перспектив розвитку у сфері топографогеодезичної та земельно-кадастрової діяльності, їх впливу на систему освіти, євроінтеграційних і глобалізаційних процесів. Запропоновано й обгрунтовано структурну модель підготовки фахівців-землевпорядників в університетах України. Визначено й описано компоненти моделі, які становлять цільовий, концептуальний, теоретично-методологічний, процесуально-змістовий, навчально-технологічний, результативний блоки. Сформульовано завдання підготовки майбутніх землевпорядників для потреб галузі геодезії та землеустрою. Розглянуто професійну підготовку майбутнього фахівця як педагогічний процес університетської освіти, результатом якого $є$ формування та розвиток його професійної готовності. Вирізнено основнінапрями вдосконалення підготовки фахівців сфери геодезії та землеустрою, а саме: використання інформаційних технологій; застосування мультимедійних засобів; використання інтерактивних методів. Визначено перелік компетентностей, які дають можливість випускнику закладу вищої освіти виконувати професійні обов'язки в структурних підрозділах Держгеокадастру України, проектних організаціях, а саме: загальні компетентності, професійні компетентності землевпорядника, фахові компетентності в галузі геодезії та землеустрою. Розроблено діагностичний інструментарій, який передбачав добір стандартизованих та авторських методик для визначення компонентів у структурі готовності фахівця до професійної діяльності. Охарактеризовано компоненти результативного блоку структурної моделі, а саме: діяльнісно-операційний; інформаційнотехнічний; когнітивний; мотиваційний; особистісно-творчий. 


\title{
PROFESSIONALS' TRAINING IN THE FIELD OF GEODESY AND LAND MANAGEMENT IN CONDITIONS OF GLOBALIZATION AND EUROPEAN INTEGRATION
}

\author{
Rusina N. G. \\ Candidate of Pedagogical Sciences, \\ Lecturer at the Technical Department \\ Separated subdivision of National University of Life \\ and Environmental Sciences of Ukraine "Rivne college" \\ Kopernyka str., 44, Rivne, Ukraine \\ orcid.org/0000-0001-5826-8788 \\ RusinaN@i.ua
}

\begin{abstract}
Key words:
land management, specialist in the field of geodesy and land management, modernization of the sector (industry modernization), structural model of training, diagnostic methods for checking the formation of readiness components, Information Technology, traditional and interactive methods.
\end{abstract}

\begin{abstract}
The article analyzes the current tendencies of training specialists in geodesy and land management taking into account the prospects of development in the field of topographical and geodetic and land-cadastral activities, their impact on the educational system, European integration and globalization processes. The structural model of land management specialists' training in Ukrainian universities is proposed and substantiated. The components of the model, which are the target, conceptual, theoretical-methodological, procedural-substantive, educational-technological, productive blocks, are determined and described. The task of training future land surveyors for the needs of the field of geodesy and land management is formulated. The professional training of the future specialist as a pedagogical process of university education, the result of which is the formation and development of his professional readiness, is considered. Pointed out the main directions of improving and training the specialists in the field of geodesy and land management, in particular: using the information technologies; using the multimedia; using the interactive methods. The list of competencies that make it possible for a graduate of a higher education institution to perform professional duties in the structural divisions of the State Geodetic Committee of Ukraine, project organizations, namely: general competencies, professional competence of the land surveyor, professional competence in the field of geodesy and land management, is determined. The diagnostic toolkit was developed, which included the selection of standardized and authored methods for determining the components in the structure of the readiness the specialists to professional activity. The components of the effective block of the structural model are characterized, namely: activity-operational; informational and technical; cognitive; motivational personal and creative.
\end{abstract}

Постановка проблеми. Сучасний рівень науково-технічного розвитку у сфері геодезичної й картографічної діяльності пов'язаний із використанням супутникових геодезичних методів, широким упровадженням нових технічних засобів і технологій створення цифрової картографічної продукції, геоінформаційних систем, вимагає наявності висококваліфікованих фахівців, здатних вирішувати складні виробничі й наукові завдання в галузі геодезії, картографії та землеустрою. Освіта в галузі геодезії та землеустрою - це не тільки галузева освіта в рамках системи освіти України, а й інструмент розвитку цієї галузі. Геодезичне й землевпорядне виробництво - це галузь, яка має специфічні відмінності від інших галузей. Ці відмінності необхідно враховувати під час формування освітніх послуг і забезпечення якості освіти. Крім того, означене виробництво формує ринок праці для осіб, які отримали геодезичну та землевпорядну освіту.

Основними роботодавцями землевпорядників $\epsilon$ державні організації й приватні підприємства, муніципалітети й органи територіального управління, яким потрібні висококваліфіковані фахівці. Це зумовлює необхідність підготовки відповідних фахівців - висококваліфікованих бакалаврів, спеціалістів і магістрів за професійним спрямуванням «Геодезія та землеустрій», які здатні комплек- 
сно вирішувати завдання управління земельними ресурсами в різних галузях господарства, виконувати проектувальну, організаційну, управлінську, виконавську функції, здійснювати наукові дослідження на високому рівні [1].

Проблемі змісту землевпорядної та геодезичної освіти в Україні присвячено дослідження Д. Гнатковича, О. Панчука, А. Третяк, В. Кривова, О. Лозового, М. Ступеня й інших науковців. Серед робіт зарубіжних учених варто відмітити праці Ф. Масума, Л. Гроенендіка, Р. Мансбергера, О. Мартіна, Б. Маркуса, С. Енемарка. Наукові праці вчених присвячені проблемам сучасних тенденцій удосконалення професійної підготовки майбутніх землевпорядників [2], вимогам до майбутніх фахівців у галузі геодезії та землеустрою [3], особливостям підготовки здобувачів освіти спеціальності «Геодезія та землеустрій» [4; 5] та аналізу глобальних трендів і перспектив розвитку топографо-геодезичної, кадастрово-реєстраційної та оціночної діяльності, а також визначенню на цій основі напрямів адаптації змісту геодезичної та землевпорядної освіти до потреб національного та світового ринку інженерних послуг [6]. Відповідно, можна стверджувати, що питання розроблення моделі підготовки фахівців галузі геодезії та землеустрою в Україні на основі європейського досвіду практично відсутні.

Мета статті - розроблення моделі підготовки фахівців галузі геодезії та землеустрою в Україні на основі європейського досвіду.

Виклад основного матеріалу дослідження. Голова комісії 2 FIG, професор С. Франк (США) зробив фундаментальний аналіз на тему «Професійна освіта для геодезистів» [7] на конференціï FIG [8]. Він зазначив, що геодезія $є$ професією, визнаною світовим співтовариством, і тому потребує професійного якісної освіти. Професійні геодезисти повинні навчитися не тільки технічних навичок, а й добре розбиратися в галузі математики, природничих наук, комунікацій. Вони повинні мати інтелектуальні та соціальні навички.

У доповіді С. Франк розмежував технічні геодезичні знання й навички; професійні геодезичні знання й навички; професійні інтелектуальні знання й навички; професійні соціальні знання й навички. Ці чотири компоненти визначають фахівця в галузі геодезії як людину, яка отримала базову освіту; фахівця в галузі професійної діяльності; творчу людину, здатну здійснювати керівництво іншими людьми, а також ставити й вирішувати нові завдання; людину суспільства, здатну вирішувати завдання в рамках розвитку людства й прогресу [7]. Із цього випливає, що професійний фахівець повинен знати основи управління та законодавство, володіти творчими здібностями вирішувати нетривіальні завдання.
Відзначимо, професійна підготовка майбутнього фахівця - це педагогічний процес університетської освіти, результатом якого є формування та розвиток професійної його готовності. Він проявляється у формах активності й визначає здібності ставити перед собою професійні цілі, обирати способи їх досягнення, здійснювати самоконтроль за виконанням власних дій і прогнозувати шляхи підвищення продуктивності роботи в професійному напрямі. Модель сучасного фахівця становить сукупність взаємопов'язаних частин: зовнішні чинники міжнародного ринку праці, що вимагає самостійності фахівця; внутрішні чинники державного впливу, щодо відповідності вимогам державного стандарту; вимоги професії, що передбачають певний склад умінь [9].

В аспекті надання професійної освіти С. Франк [8] наголосив, що перспективною є тенденція на електронне навчання. Він зазначив, що дослідження показали більш високий рівень підготовки студентів у разі поєднання традиційних методів та електронного навчання. На його думку, фахівцям у галузі землекористування необхідно ширше викладати інноватику й надавати знання в галузі інновацій.

Зазначимо, продукція освіти складається 3 технічної кваліфікації (фактичні знання й уміння, необхідні для виконання робіт, ноу-хау, які передаються досвідченими викладачами здобувачам освіти) і формальної кваліфікації (сертифікати, дипломи, ступені, титули, необхідні для кар'єри). В останньому випадку відповідність між ноу-хау, придбаними через навчання, і вимогами роботодавців і $є$ відповідністю між ієрархіями сертифікатів про освіту й ієрархіями соціального статусу. Цікаві дослідження 3 питання активної взаємодії студентів під час навчання представлені професором з Нідерландів Л. Гроендік [10] з університету міста Твенте (Нідерланди). Під іiі керівництвом проведено експерименти 3 інформаційного взаємодії аспірантів як експертів і викладачів. Розглянуто різні схеми взаємодії. Автор [10] доводить, що активна участь студентів, магістрів та аспірантів в освітньому процесі через обмін знаннями підвищує в підсумку якість освіти й професійний рівень майбутніх фахівців. Цим створюється додатковий інформаційний освітній ресурс.

3 метою вдосконалення системи підготовки фахівців галузі геодезіі та землеустрою розроблено модель, яка передбачає шість структурних блоків: цільовий; концептуальний; теоретично-методологічний; процесуально-змістовий; навчально-технологічний; результативний (рис. 1).

Зазначені компоненти моделі взаємопов'язані між собою, забезпечують цілісність і поетапність процесу підготовки майбутніх землевпорядників до професійної діяльності у сфері геодезії та землеустрою. 


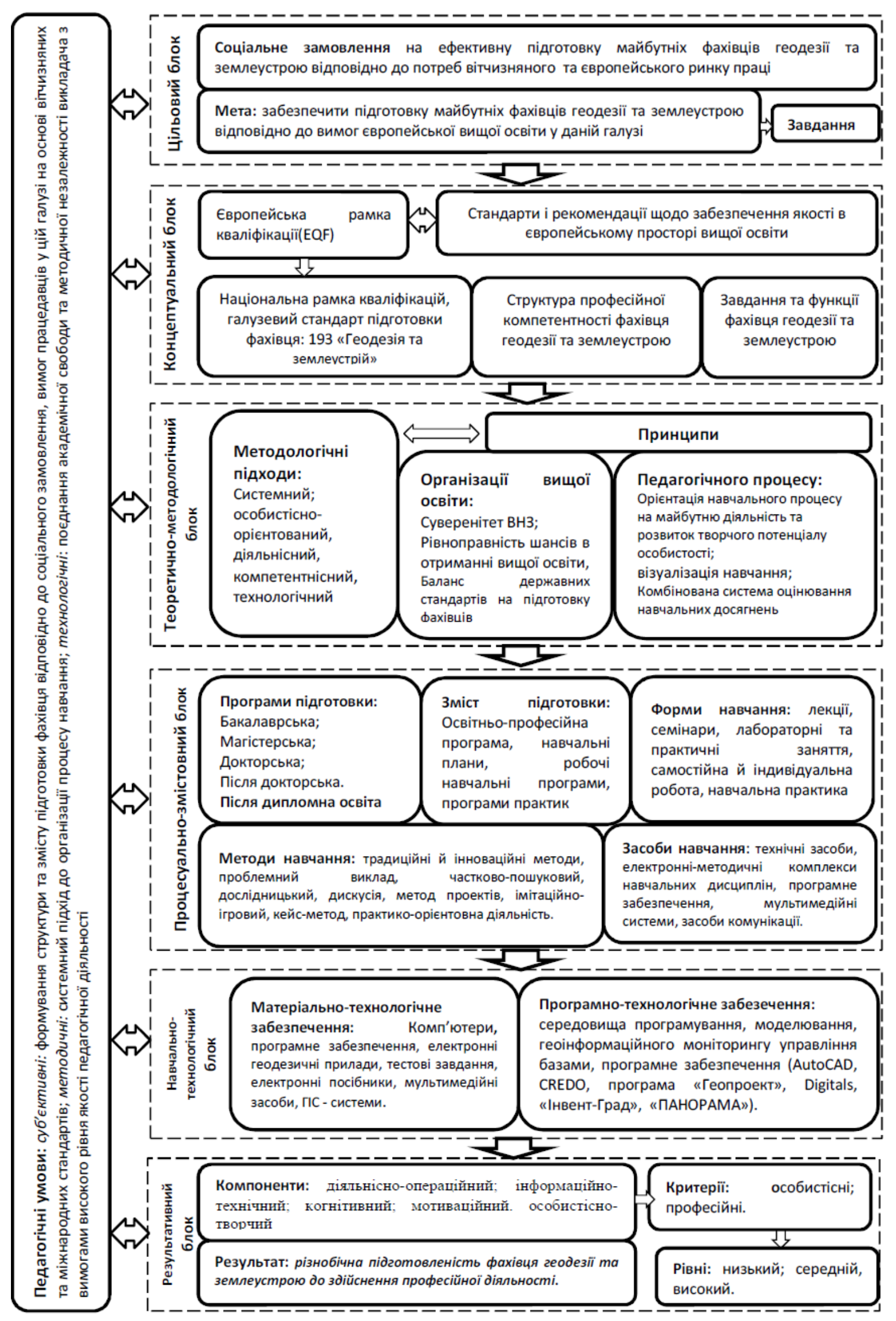

Рис. 1. Структурна модель підготовки фахівців геодезії та землеустрою в Україні на основі свропейського досвіду 
Цільовий блок моделі підготовки розроблено 3 урахуванням наявності соціального замовлення на підготовку фахівців геодезії та землеустрою. Блок визначає мету моделі. Відповідно до мети, сформульовано завдання підготовки майбутніх землевпорядників для потреб галузі геодезії та землеустрою. У концептуальному блоці виділено вихідні положення, на основі яких здійснюється підготовка землевпорядників, а саме: стандарти освіти й вимоги роботодавців. Теоретико-методологічний блок моделі відповідає сучасним тенденціям в освітній галузі стосовно використання інформаційних технологій і зміни ролі викладача. Професійна підготовка майбутніх землевпорядників будується згідно з принципами навчання, серед яких ми виокремлюємо організації вищої освіти загалом і педагогічного процесу. Процесуально-змістовий блок моделі визначає особливості підготовки землевпорядників до професійної діяльності в умовах широкого доступу до світових інформаційних ресурсів і функціонування системи електронного навчання, містить програми підготовки, зміст підготовки, форми, методи й засоби навчання, які дають можливість реалізувати завдання.

Процес підготовки реалізується за допомогою дисциплін, зміст яких відображено в державних стандартах і навчальній документації. Організаційні форми навчання є традиційними, але важливо використовувати такі форми навчання, які розвивають у студентів здатність до самовдосконалення, командної роботи, кооперації, оскільки вони є необхідними для ефективної професійної діяльності в галузі геодезії та землеустрою. Успішність процесу підготовки землевпорядників значною мірою залежить від вдалого вибору засобів навчання. Отже, під час освітнього процесу застосовують традиційні та інноваційні засоби. До інноваційних засобів навчання ми зараховуємо віртуальні лабораторії, електронні підручники, Moodle- та Google-технології.

Навчально-технологічний блок пов'язаний 3 усіма попередніми, оскільки базується на визначальних позиціях, які сформовані на концептуальному, теоретично-методологічному й процесуаль- но-змістовому рівнях. Програмно-технологічний складник блоку має значні особливості під час підготовки землевпорядника, оскільки потребує вивчення особливих ГІС-технологій, пов'язаних із професійною діяльністю в галузі землеустрою, а тому й навчальні програмні середовища мають бути доступними студентам. Усі складники моделі будуть ефективно реалізовані лише в разі виконання низки педагогічних умов.

Заключним блоком пропонованої нами структурно-змістової моделі підготовки землевпорядників у закладах вищої освіти є результативний, що охоплює рівні, критерії й компоненти моніторингу рівня готовності майбутнього фахівця 3 геодезії та землеустрою до професійної діяльності. Результатом моделі є різнобічна підготовленість фахівця геодезії та землеустрою до здійснення професійної діяльності.

Висновки. В умовах «цифрової економіки» інтеграція української науки в європейський дослідницький простір забезпечить можливість розвитку передових наукових ідей, участь у міждисциплінарних проектах, що зосереджуються на перспективних ідеях, технологіях та інноваціях. Усі ці підходи мають відображатися в освітніх програмах спеціальності 193 «Геодезія та землеустрій». Підготовка таких фахівців є актуальною, має свої особливості, пов'язані зі специфікою галузі. Саме структурна модель, яка обгрунтована в дослідженні, алгоритмізує процес підготовки землевпорядника в університетах України. Вища освіта 3 геодезії та землеустрою в умовах глобалізації та євроінтеграції повинна здійснюватися на основі цільового, концептуального, методологічного, навчально-технологічного, процесуально-змістового й результативно-оціночного компонентів. Питання, порушені в статті, $€$ актуальними та потребують подальших наукових досліджень, зокрема реалізація структурної моделі підготовки фахівців у галузі геодезії та землеустрою в навчальному процесі закладів вищої освіти. Також потребує дослідження запровадження передових технологій і найкращих європейських галузевих практик у робочі програми фахових навчальних дисциплін.

\section{Література}

1. Коваленко С.В. Особливості підготовки фахівців професійного спрямування «Геодезія, картографія та землеустрій» у Чернігівському національному технологічному університеті. Технічні науки та технологіï. 2015. № 1 (1). С. 205-211.

2. Третяком А.М., Третяком В.М., Пендзей Л.П. Стан та проблеми підготовки, підвищення кваліфікації і перепідготовки кадрів у сфері землеустрою. Землеустрій, кадастр і моніторинг земель. 2016. № 1-2. С. 128-135.

3. Професія землевпорядкування на ринку праці потребує розширення спеціальностей та спеціалізацій / А.М. Третяком, В.М. Третяком, Й.М. Дорошом, О.С. Дорош. Землевпорядний вісник. 2018. № 4. C. 22-27. 
4. Боровий В.О. Введена нова спеціальність «Геодезія та землеустрій». Землевпорядний вісник. 2016. № 1. С. 17-19.

5. Боровий В.О. Формування нової спеціальності «Геодезія та землеустрій», як доцільніше організувати навчання та практику? Землевпорядний вісник. 2016. № 4. С. 42-52.

6. Мартин А. Вища освіта з геодезії та землеустрою: час змінювати пріоритети навчання? Землевпорядний вісник. 2018. № 2. С. 30-36.

7. Голубев В.В., Фартукова И.С., Цветков В.Я. Международная Конференция «Образование в области геодезии, кадастра и землеустройства: тенденции глобализации и конвергенции». Геодезия и картография. 2012. № 10. С. 56-59.

8. Frank S. Professional Education for Surveyors. URL: http:// fig.miigaik.ru /papers/02_steven_frank_full_ text.pdf (дата звернення: 20.08.2020).

9. Шульга Л.В., Бражник Л.В., Вакуленко Ю.В. Підвищення якості університетської освіти: Професійна та практична підготовка фахівців. URL: https://www.pdaa.edu.ua/sites/default/files/nppdaa/6.2/335. pdf/ (дата звернення: 05.01. 2020).

10. Groenendijk L. Developing a curriculum in land administration. Can students be of help? URL: http://fig. miigaik.ru/papers/4_liza_groenendijk_26102012.pdf (дата звернення: 05.01.2020).

\section{References}

1. Kovalenko S. (2015.) Osoblyvosti pidhotovky fakhivtsiv profesiinoho spriamuvannia «Heodeziia, kartohrafiia ta zemleustrii» $\mathrm{u}$ Chernihivskomu natsionalnomu tekhnolohichnomu universyteti [Peculiarities of training of specialists in «Geodesy, cartography and land management» in Chernihiv national university of technology]. Technical sciences and technologies. № 1 (1). P. 205-211 (in Ukrainian).

2. Tretiakom A.M., Tretiakom V.M., Pendzei L.P. (2016) Stan ta problemy pidhotovky, pidvyshchennia kvalifikatsii i perepidhotovky kadriv u sferi zemleustroiu. [Status and problems of training, advanced training and retraining in the field of land management. Land management, cadastre and land monitoring]. Land management, cadastre and land monitoring. № 1-2. P. 128-135 (in Ukrainian).

3. Tretiakom A.M., Tretiakom V.M., Doroshom Y.M., Dorosh O.S. (2018) Profesiia zemlevporiadkuvannia na rynku pratsi potrebuie rozshyrennia spetsialnostei ta spetsializatsii [The profession of land management in the labor market needs to expand specialties and specializations]. Land Management Bulletin. № 4. P. 22-27 (in Ukrainian).

4. Borovyi V.O. (2016)Vvedena nova spetsialnist «Heodeziia ta zemleustrii» [A new specialty «Geodesy and Land Management» was introduced]. Land Management Bulleti. № 1. P. 17-19 (in Ukrainian).

5. Borovyi V.O. (2016) Formuvannia novoi spetsialnosti «Heodeziia ta zemleustrii», yak dotsilnishe orhanizuvaty navchannia ta praktyku?[. Formation of a new specialty «Geodesy and Land Management», how to organize training and practice] Land Management Bulleti. № 4. P. 42-52 (in Ukrainian).

6. Martyn A. (2018) Vyshcha osvita z heodezii ta zemleustroiu: chas zminiuvaty priorytety navchannia? [Higher education in geodesy and land management: time to change learning priorities?]. Land Management Bulleti. № 2. P. 30-36 (in Ukrainian).

7. Golubev V.V., Fartukova I.S., Tsvetkov V.Ya. (2012) Mezhdunarodnaya Konferentsiya «Obrazovanie v oblasti geodezii, kadastra i zemleustroystva: tendentsii globalizatsii i konvergentsii» [International Conference «Education in Geodesy, Cadastre and Land Management: Trends in Globalization and Convergence»]. Geodesy and cartography. № 10. P. 56-59 (in Russian).

8. Frank S. Professional Education for Surveyors. [Online]. Available: http:// fig.miigaik.ru /papers/02_steven frank full text.pdf. Accessed on: 20.08.2020 (in English).

9. Shulha L.V., Brazhnyk L.V., Vakulenko Yu.V. Pidvyshchennia yakosti universytetskoi osvity: Profesiina ta praktychna pidhotovka fakhivtsiv [Improving the quality of university education: Professional and practical training]. [Online]. Available: https://www.pdaa.edu.ua/sites/default/files/nppdaa/6.2/335.pdf/ Accessed on: 05.01. 2018 (in Ukrainian).

10. Groenendijk L. Developing a curriculum in land administration. Can students be of help? [Online]. Available: http://fig.miigaik.ru/papers/ 4_liza_groenendijk_26102012.pdf. Accessed on: 05.01. 2018 (in English). 